\title{
Establishing soil loss tolerance: an overview
}

\author{
Costanza Di Stefano, Vito Ferro \\ Department of Agricultural and Forestal Sciences, University of Palermo, Italy
}

\begin{abstract}
Soil loss tolerance is a criterion for establishing if a soil is potentially subjected to erosion risk, productivity loss and if a river presents downstream over-sedimentation or other off-site effects are present at basin scale. At first this paper reviews the concept of tolerable soil loss and summarises the available definitions and the knowledge on the recommended values and evaluating criteria. Then a threshold soil loss value, at the annual temporal scale, established for limiting riling was used for defining the classical soil loss tolerance. Finally, some research needs on tolerable soil loss are listed.
\end{abstract}

\section{Introduction}

Soil degradation implies a long-term decline in its productivity and it determines reduction in some attributes of soil having specific functions of value to humans (Alexander, 1988).

Soil degradation by accelerated erosion is a serious problem and will remain so during the $21^{\text {st }}$ century and its severity and economic and environmental impacts are debatable (Lal, 2001).

Soil erosion on cultivated lands has received much concern since it is considered to be one of the most critical forms of degradation (Montgomery, 2007; Cerdà et al., 2009; Zhao et al., 2013).

Soil erosion can be a manifestation of soil degradation because it involves physical removal of soil in a vertical and/or horizontal direc-

Correspondence: Vito Ferro, Department of Agricultural and Forestal Sciences, University of Palermo, viale delle Scienze, 90128 Palermo, Italy. Tel.: +39.091.23897068

E-mail: vito.ferro@unipa.it

Key words: Soil erosion; soil loss; soil loss tolerance; universal soil loss equation.

Conflict of interest: the authors declare no potential conflict of interest.

Received for publication: 16 April 2016.

Accepted for publication: 21 June 2016.

(C) Copyright C. Di Stefano and V. Ferro, 2016

Licensee PAGEPress, Italy

Journal of Agricultural Engineering 2016; XLVII:560

doi:10.4081/jae.2016.560

This article is distributed under the terms of the Creative Commons Attribution Noncommercial License (by-nc 4.0) which permits any noncommercial use, distribution, and reproduction in any medium, provided the original author(s) and source are credited. tion and degrades soil quality. Soil erosion is a natural process and its acceleration, due to anthropogenic perturbations, can have severe impacts on soil and environmental quality.

By contributing to the removal of soil material and the deterioration of the soil system, soil erosion directly affects the quality of the soil, its agricultural productivity and the biological diversity that is stored or lives in soil. Soil erosion also affects water quantity (loss of water holding capacity of soils) and water quality (turbidity through increased sediments in water). As soil formation is a very slow process, soil should be considered essentially as a non-renewable resource and its damage could be irreversible.

Soil erosion has both on-farm and off-farm impacts. Reduction of soil depth can impair the land's productivity and sediment transport can degrade streams and lakes (Uri, 2000). When soil particles wash off a field, they may be transported by runoff until discharged into a water body. Not all agricultural constituents that are transported from a field reach water systems but a significant quote of finer particles, which are the most chemical active, is discharged. Once agricultural pollutants enter a water system, they lower water quality and impose economic losses on water users.

The EU soil thematic strategy of the European Commission (2006) established that soil is essentially a non-renewable resource and a very dynamic system, which performs many functions and delivers services vital to human activities and ecosystems survival. The pedogenetic processes responsible of soil formation are very slow, requiring from 200 to 1000 hundreds to thousands years to form a few centimeters of topsoil under normal agricultural condition (Kendall and Pimentel, 1994; Bazzoffi, 2009). A European Commission analysis indicates that soil erosion continues to be more than soil formation across the European Union, but that the European agricultural policy is working to reduce this gap (Panagos et al., 2015). The amount of soil lost by water erosion in Europe determines an estimated economic loss of about $\$ 20$ billion per year, based on a restoration cost of $\$ 20$ per ton (Panagos et al., 2015). In the period 2000-2010, soil conservation measures carried out by the Common Agricultural Policy reduced soil loss by $20 \%$ in cultivated areas. Soil formation due to rock weathering is affected by changes in rainfall amount, average temperatures, water infiltration rate, type of soil cover and other natural and anthropic factors. Available data on soil formation (Owen and Watson, 1979; Friend, 1992; Miklos, 1992; Wakastsuki and Rasyidin, 1992) are rare and are affected by errors due to the difficulty of the measurement carried out at the soil-rock border (Sparovek and De Jong, 1997). The most reliable estimates of rates of soil formation from consolidated sediments or bedrock are based on small watershed studies. Data from these studies have been reviewed and rates of soil formation were computed from the following mass balance approximation of Barth's (1961) equation (Alexander, 1988):

$W=D+S$

where:

$W$ is the mass of rock or consolidated sediments weathered; 
$S$ is the mass of residue or soil formed from the weathered lithic or para-lithic material; and

$D$ is the mass of dissolved solids removed by runoff from the soil-parent material system.

If the soil erosion rate increases may become greater than the soil formation rate resulting in a reduced soil depth soil. The use and management of soils must consider how to preserve it from excessive depth loss and the consequent degradation of its physical, chemical and biological properties.

Soil conservation polices have existed in the United States for more than 70 years. Initially, these polices focused on the on-farm benefits of keeping soil on the land and the United States Department of Agriculture (USDA) used a number of policy tools for improving conservation practices and programs. These tools require the implementation of specified conservation practices or the avoidance of some land use changes if a farmer wants to be eligible for an agricultural program payment.

Payment for environmental services has assumed an increasing importance in the preservation or restoration of ecosystem services related to water resources. Through economic mechanisms, human actions working towards maintaining or improving the quantity and the quality of natural resources, such as controlling soil erosion, are encouraged (Lenka et al., 2014).

Out of the paradox between intolerable soil loss due to man-accelerated erosion and the inevitable soil loss due to geologic erosion came the idea to establish a tolerable soil loss (Schmidt, 1982). Soil conservationists realised that a quantitative standard was needed to evaluate the effectiveness of erosion control measures and this standard is commonly named tolerable soil loss, $T_{S L}$ (Johnson, 1987).

Smith (1941) was probably the first student of soil erosion and erosion control (Johnson, 1987), who underlined the need of defining both a standard for erosion control and the concept of permissible soil loss. Smith (1941) stated that is tolerable a soil loss rate which will permit at least a constant or preferably an increasing time gradient of soil fertility. Focusing the definition of $T_{S L}$ on soil fertility conservation, Smith (1941) implicitly established that tolerable soil loss values can be affected by the possibility to threat soil with fertilisers to replace nutrient contents lost through erosion.

In 1947, probably for the first time (Browning et al., 1947) a soil loss tolerance in cropland was formally applied to some soil types and, at this time, it was defined as the maximum average annual permissible soil loss without decreasing productivity.

Smith and Whitt (1948) established that the ultimate objective of soil conservation is to maintain soil fertility and hence crop production, indefinitely. Any soil loss that permits a decline in fertility must be avoided. This definition of $T_{S L}$ is clearly focused on preserving agricultural productivity of soils in situ and is based on the assumption that soil organic matter content is the main indicator of soil fertility.

Widespread application of the soil loss tolerance concept started since 1962 , when the $T_{S L}$ values were determined by U.S. Soil Conservation Service for most of the American soil types. All soils in the USA have been assigned $T_{S L}$ values ranging from 4.5 to $11.2 \mathrm{t} \mathrm{ha}^{-1}$ year-1. In that moment, the soil loss tolerance was defined as the maximum level of soil erosion that will permit a high level of crop productivity to be sustained economically and indefinitely (Wischmeier and Smith, 1978; Renard et al., 1997; Lal, 2001). In any way even the lowest $T_{S L}$ value is many times greater than the soil formation rate under natural conditions and this system is characterised by a scientific weakness due to the lack of scientific data supporting both an adequate prediction of soil formation rate and the effects of soil erosion on soil productivity.

Williams (1981) asserted that There is essentially non research base to support soil loss tolerance values; they were established and revised on the basis of collective judgments by soil scientists.

Although the original soil loss tolerance definition was concerned with a physical limitation of the soil production, many other damages can be incorporated into $T_{S L}$ values. Some of these are off-site damages related to nutrient loss or gully formation, while others are off-site damages concerning water quality and river sedimentation. For this reason Larson (1981) proposed a two-level approach in which the lower limit $T_{S L I}$ value can be established for maintaining an on-site soil productivity objective and an upper limit $T_{L S 2}$ value can be used to limit offsite effects such as water pollution and reservoir sedimentation.

There has been little research on quantitative assessment of soil loss tolerance and the parameters used for this assessment have been different for many studies (Lal, 1998; Lakaria et al., 2008).

In this paper the research results on soil loss tolerance are summarised with the aim to establish criteria for evaluating soil loss tolerance and to propose new research needs.

\section{Defining soil loss tolerance}

$T_{S L}$ value is a concept useful to judge if a soil has potential risk of erosion, productivity loss and off-site damages as river oversedimentation or reservoir sedimentation (Li et al., 2009). Soil loss tolerance is also a useful criterion to design conservation practices and works for erosion controlling or can be used as an indicator of soil quality (Johnson, 2005; Bagarello and Ferro, 2006). The term tolerable soil erosion is used when referring to soil lost by erosion in the context of soil conservation, soil loss tolerance or tolerable soil loss is the variable used to express the concept and it is measured as tha $^{-1}$ year $^{-1}$. Table 1 summarises the different definitions of tolerable soil erosion available in literature.

The concept of tolerable soil loss based on soil productive is reductive and neglecting the off-site effects does not reach a comprehensive environmental approach (Bazzoffi, 2009).

According to Verheijen et al. (2009) reviewing the available definitions for tolerable soil loss two different approaches emerge: i) establishing $T_{S L}$ as the value able to maintain the dynamic equilibrium of soil quantity (as mass or volume) in any site and under any circumstances; ii) relating tolerable soil loss to the biomass production function of soil. The first approach focuses on soil quantity while the second one focuses only on the biomass (particularly crops) production function of soil. The first definition considers tolerable a soil loss, which does not exceed the soil formation rate while the second definition links the tolerated value to the performance of a particular soil function.

Verheijen et al. (2009) suggested to integrate both approaches and proposed a more holistic definition of tolerable soil erosion as any mean annual cumulative (all erosion types combined) soil erosion rate at which a deterioration of one or more (primary) soil functions (e.g., habitat, production, storing, filtering) does not occur.

Soil functions can generally be judged not to deteriorate when soil erosion corresponds to geological or normal conditions.

The USDA (1956) defined the following top ten influencing factors of tolerable soil loss for a particular soil (Li et al., 2009): the rate of soil formation from parent material; the rate of topsoil formation from subsoil; reduction of crop yield by erosion; soil depth; changes in soil properties favorable for plant growth caused by erosion; loss of plant nutrients by erosion; the likelihood of rill and gully formation; sediment deposition problems within a field; sediment delivery from the erosion site; the availability of feasible, economic, culturally and socially acceptable, as well as sustainable soil conservation practices. 


\section{Recomended soil loss tolerance values}

The generally accepted maximum limit of soil loss or $T_{S L}$ value is 11.2 $\mathrm{Mg} \mathrm{ha}^{-1}$ year-1 (Wishmeier and Smith, 1978). Browning et al. (1947) identified for 12 Midwest soils the maximum average annual permissible soil loss without decreasing productivity. Erosion loss is more serious on soils with heavy infertile subsoil than on loess soils with uniform texture. The main determining factor was the loss of productivity per $2.5 \mathrm{~cm}$ of soil lost through erosion.

Guidelines for evaluating $T_{S L}$ value were formulated in the early 1960 s after about 15 years of discussion by soil scientists, agronomists, and others. In 1961 and 1962, Soil Conservation Service held six regional soil loss prediction workshops attended by agronomists, geologists, and soil conservationists. At these workshops the value 5 tons $\mathrm{ha}^{-1}$ year $^{-1}$ was set as maximum tolerance. The procedure used in assigning $T_{S L}$ value has relied strictly on multiple judgments of informed scientists. In accordance with the current state of scientific knowledge for Europe, tolerable soil loss, for hillslope soils overlying hard rock parent material, range from 0.3 to $1.4 \mathrm{t} \mathrm{ha}^{-1}$ year $^{-1}$ depending on the driving factors of soil formation i.e., weathering (e.g., parent material, climate, land use) and desert-source dust deposition (e.g., geographic position; distance to source). Huber et al. (2008) raise the question of proposing different threshold values for tolerable soil erosion rates in different parts of Europe, e.g., higher for southern Europe than for northern Europe. It should be noted that, in its proposal for a Soil Framework Directive (EC, 2006), the European Commission has refrained from suggesting a uniform soil erosion target rate for the EU. It has on the contrary suggested that Member States should themselves set appropriate target rates, which can vary from area to area in their national territory to ensure the protection of soil functions and a sustainable soil use. Only two European countries are currently known to have established tolerable rates of erosion thresholds. In Switzerland, the tolerated soil erosion is either 1 or $2 \mathrm{tha}^{-1}$ year-1 depending on the vulnerability of the soil to erosion. In Norway, the threshold is set at 2

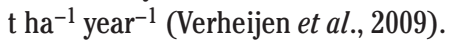

Europe's environment assessment (European Environment Agency, 1998) considered that tolerable soil loss varies between different soil depths, types and agro-climatic conditions, but typically ranges from 1 $\mathrm{t} \mathrm{ha}^{-1}$ year-1 on shallow sandy soils to $5 \mathrm{t} \mathrm{ha}^{-1}$ year-1 on deeper welldeveloped soil. With a very slow rate of soil formation, any soil loss of more than $1 \mathrm{t} \mathrm{ha}^{-1}$ year-1 $^{-1}$ can be considered to cause irreversible damage to soil quality within a time span of 50-100 years.
The Organisation for Economic Co-operation and Development (OECD) indicates as tolerable a soil erosion rate less than $6 \mathrm{t} \mathrm{ha}^{-1}$ year-1. Bazzoffi (2009) showed the environment minimum requirements for different ecosystems; these values represent the best compromise between the two necessities of reducing soil erosion to minimum rates and making it possible the continuation of the agricultural activities in the area. Nevertheless, the values reported by Bazzoffi (2009) never exceed $3 \mathrm{t} \mathrm{ha}^{-1}$ year-1. This value, compared with the $T$ value indicated by OECD ( $6 \mathrm{t} \mathrm{ha}^{-1}$ year-1) can be considered very suitable to achieve a good performance of the function soil erosion control.

\section{Evaluating soil loss tolerance}

According to Toy et al. (2002) soil loss tolerance concept is a powerful conservation-planning tool because both technical and nontechnical elements are combined into a single number.

The universal soil loss equation (USLE) by Wischmeier and Smith (1978) was also used with the $T_{S L}$ value ( $\mathrm{t} \mathrm{ha}^{-1}$ year $^{-1}$ ) for conservation design:

$$
\frac{T_{S L}}{R K S}=L C P
$$

in which:

$R$ is the rainfall erosivity factor;

$K$ is the soil erodibility factor;

$S$ is the slope steepness factor;

$L$ is the slope length factor;

$C$ is the crop factor; and

$P$ is the practice and management factor.

Using Eq. (2), as it is known, the factors $L, C$ and $P$ can be modified for obtaining a soil loss value less than the tolerable soil loss.

Soil conservation strategies designed by average weather conditions can provide adequate erosion control in most years but unacceptable sediment yield can occur for the largest erosion-producing events (Gonzales-Hildalgo et al., 2010, 2012). Therefore, it seems reasonable to suggest that conservation strategies should be developed taking into account large storms rather than average weather conditions (Bagarello et al., 2010; Strohmeier et al., 2016).

From an engineering point of view, the reference severe storm has

Table 1. Definitions of tolerable soil erosion.

\begin{tabular}{|c|c|}
\hline Authors & Definitions \\
\hline Smith (1941) & A tolerable soil loss rate will permit at least a constant or preferably an increasing time gradient of soil fertility \\
\hline Browning et al. (1947) & $\begin{array}{l}\text { A soil loss tolerance in cropland is defined as the maximum average annual permissible soil loss without decreasing } \\
\text { productivity }\end{array}$ \\
\hline Smith and Whitt (1948) & Tolerable soil loss is any soil loss that permits a decline in fertility must be avoided \\
\hline U.S. Soil Conservation Service & $\begin{array}{l}\text { Soil loss tolerance is the maximum level of soil erosion that will permit a high level of crop } \\
\text { productivity to be sustained economically and indefinitely }\end{array}$ \\
\hline Verheijen et al. (2009) & $\begin{array}{l}\text { Tolerable soil loss is any mean annual cumulative (all erosion types combined) soil erosion rate at which } \\
\text { a deterioration of one or more (primary) soil functions (e.g., habitat, production, storing, filtering) does not occur }\end{array}$ \\
\hline Bagarello et al. (2015) & $\begin{array}{l}\text { The classical soil loss tolerance (11.5 } \mathrm{t} \mathrm{ha}^{-1} \text { year }^{-1} \text { is a soil loss having a return period equal to } 2 \text { years } \\
\text { The occurrence of soil loss equal to or lower than } 11.5 \mathrm{t} \mathrm{ha}^{-1} \text { year-1 does not ensure absence of rills }\end{array}$ \\
\hline Bagarello et al. (2015) & $\begin{array}{l}\text { The aim of soil conservation strategies to limit rilling can be obtained using a threshold soil loss which is greater than } \\
\text { the classical soil loss tolerance }\left(11.5 \mathrm{t} \mathrm{ha}^{-1} \mathrm{year}^{-1}\right)\end{array}$ \\
\hline
\end{tabular}


to be defined to design a soil conservation system. This design storm cannot simply be estimated when little or no erosion data exist at a site. Moreover, it cannot be assumed equal to the maximum of the available historical series since the event recurrence interval is unknown. As an alternative, the historical sequence, having a sufficient sample size, is used to develop a frequency analysis and to estimate the soil erosion variable having a given return period (Baffaut et al., 1998; Mannaerts and Gabriels, 2000). According to Larson et al. (1997), conservation systems should be designed for limiting soil loss (namely, tolerance) to the value corresponding to a return period variable from 10 to 20 years.

If a sufficiently large historical sequence of soil loss values is available then a frequency analysis can be developed and the soil erosion variable having a given return period can be estimated (Baffaut et al., 1998; Mannaerts and Gabriels, 2000). Notwithstanding the knowledge of the return period of an erosion event can be considered relevant information to design soil conservation systems, the use of frequency analysis in soil erosion studies is relatively limited (Hession et al., 1966; Baffaut et al., 1998; Mannaerts and Gabriels, 2000; Bagarello et al., 2010, 2011) probably because of the difficulty to collect a number of measurements large enough for developing statistical inference analysis. Recently Bagarello et al. (2011) carried out an investigation on statistical distribution of soil loss measurements using simultaneously operating plots of different length, $\lambda(11,22,33$ and $44 \mathrm{~m})$ at the experimental station of Sparacia (southern Italy). Using a simple normalisation technique, the analysis showed that the probability distribution of the normalised soil loss is independent of both the scale length $\lambda$ and the temporal scale, which are completely represented by the mean soil loss calculated for a given event using all replicated data collected in plots having the same length.

Using the USLE/revised USLE (RUSLE) scheme, Bagarello et al. (2011) showed that the frequency distribution of the soil loss can be obtained by the frequency distribution of the rainfall erosivity index. The soil loss corresponding to a given return period $T, \mu\left(S L_{e, T}\right)$, can be deduced by the following relationship:

$\mu\left(S L_{e, T}\right)=x_{T} M\left[\mu\left(S L_{e}\right)\right]$

where:

$\mu\left(S L_{e, T}\right)$ is the soil loss at the event temporal scale corresponding to a given $T$;

$M\left[\mu\left(S L_{e}\right)\right]$ is the mean soil loss per event; and

$x_{T}$ is the quantile of given return period which can be estimated by the following expression:

$x_{T}=\frac{R_{e, T}}{M\left(R_{e}\right)}$

where:

$R_{e, T}$ is the event rainfall erosivity index corresponding to given return period T; and

$M\left(R_{e}\right)$ is the mean value of the event rainfall erosivity index.

Eq. (4) establishes that $\mu\left(S L_{e, T}\right)$ is obtained by amplifying the mean soil loss, $M\left[\mu\left(S L_{e}\right)\right]$, by a frequency factor $x_{T}$ which is estimated by the frequency corresponding to a given return period $T$. The annual soil loss corresponding to a return period $T, \mu\left(S L_{a, T}\right)$, can be predicted by the following relationship (Bagarello et al., 2011):

$\mu\left(S L_{a, T}\right)=x_{T} M\left[\mu\left(S L_{a}\right)\right]=\frac{R_{a \cdot T}}{R} M\left[\mu\left(S L_{a}\right)\right]$

in which:

$M\left[\mu\left(S L_{a}\right)\right]$ is the mean annual soil loss;
$R_{a, T}$ is the annual rainfall erosivity factor with a $T$ years return period; and

$R$ is the rainfall factor of the USLE, i.e. the mean of the annual values.

Using the USLE for estimating the mean annual soil loss of a bare plot, Eq. (5) gives:

$\mu\left(S L_{a, T}\right)=\frac{R_{a \cdot T}}{R} M\left[\mu\left(S L_{a}\right)\right]=R_{a, T} K L S$

which can be applied to determine the expected annual soil loss of a given return period $T$.

For designing soil conservation purposes, such as predicting distance between channel terraces to control annual soil loss from a bare plot, Eq. (6) can be rewritten as follows:

$\mu\left(S L_{a, T}\right)=x_{T} R K L$

in which:

$x_{T}$ is the frequency factor corresponding to a return period $T$.

In other words, the design of a soil conservation practice needs establishing the return period $T$ and determining the corresponding frequency factor $x_{T}$.

Bagarello et al. (2011) suggested establishing, at the annual temporal scale, the frequency factor $x_{T}$ using the probability distribution of the annual soil loss or, as an approximated alternative, the annual rainfall erosivity factor.

As an example for Sicilian region, the statistical analysis of the measured annual values of the rainfall erosivity factor showed that the Weibull's distribution can be used (Ferro et al., 1991) an the following equation can be applied to estimate the frequency factor $x_{T}$ :

$x_{T}=\frac{\beta(\ln T)^{1 / \varepsilon}}{R}$

where $\beta$ and $\varepsilon$ are the two parameters of the Weibull's law, depending on the mean value, $R$, and the standard deviation, $\sigma\left(R_{a}\right)$, of the annual rainfall erosivity factor according to the following relationships (Ferro et al., 1991):

$R=\beta \Gamma\left(1+\frac{1}{\varepsilon}\right)$

$\sigma\left(R_{a}\right)=\beta\left[\Gamma\left(1+\frac{2}{\varepsilon}\right)-\Gamma^{2}\left(1+\frac{2}{\varepsilon}\right)\right]^{1 / 2}$

in which $\Gamma$ is the gamma function. The mean value $R$ can be estimated in Sicily by the following equation (Ferro et al., 1991):

$R=183.82+1.3956\left(I_{1,2} I_{6,2} I_{24,2}\right)$

in which:

$R$ is expressed in SI units (MJ mm ha ${ }^{-1} \mathrm{~h}^{-1}$ year-1 $^{-1}$ ); and

$I_{1,2}, I_{6,2}, I_{24,2}\left(\mathrm{~mm} \mathrm{~h}^{-1}\right)$ are the rainfall intensity with 1,6 and $24 \mathrm{~h}$ duration and a return period of two years, respectively.

The standard deviation $\sigma\left(R_{a}\right)$ is estimated for Sicilian region by the following equation (Ferro et al., 1991):

$\sigma\left(R_{a}\right)=-521.63+1.38 R$

in which $R$ is expressed in SI units.

According to this result, soil conservation works has to be designed 
using USLE/RUSLE and calculating the soil loss corresponding to an annual tolerable soil loss $T_{S L A}$ having a given return period $T$ (Eq .7):

$T_{S L A}=x_{T} R K L S C P$

Bagarello et al. (2010, 2015) developed a frequency analysis using the annual maximum soil loss measurements, collected in the period 1999-2012 at Sparacia experimental area, normalised by the mean soil loss measured at a given temporal and spatial scale. The empirical frequency distribution of the normalised variable $x$ was well fitted by two Gumbel's theoretical probability distributions discriminated by a value of the normalised variable equal to 2 , which corresponds to a return period $T$ approximately equal to 25 years.

The analysis of Bagarello et al. (2015) showed that both the return period of the classical soil loss tolerance ( $11.5 \mathrm{t} \mathrm{ha}^{-1}$ year-1 $\left.^{-1}\right)$ is equal to 2 years and the occurrence of soil loss equal to or lower than $11.5 \mathrm{t} \mathrm{ha}^{-1}$ year-1 does not ensure absence of rills.

Taking into account the results regarding rill frequency, Bagarello $\mathrm{et}$ al. (2015) also established that the aim of soil conservation strategies to limit rilling can be obtained using a threshold soil loss which is greater than the classical soil loss tolerance (11.5 $\mathrm{tha}^{-1}$ year-1).

Eq. (13) shows that the threshold soil loss value at annual scale, $T_{S L A}$, is equal twice the mean annual value of soil loss calculated by USLE/RUSLE. Taking into account that the maximum annual value of the tolerable soil loss $T_{S L A, m}$ corresponds to $C=P=1$, Eq. (13) allows to calculate this reference value:

$T_{S L A, m}=2 R K L S$

Therefore the annual value of the tolerable soil loss can be set equal to twice the mean annual value of the maximum soil loss ( $R K L S$ ) calculated by USLE/RUSLE.

Soil erosion models and risk maps are useful tools that should assist public authorities and political decision makers to establish land use and soil conservation strategies (Bagarello et al., 2016). The USLE scheme (Wischmeier and Smith, 1978) was used in Sicily for developing maps representing the spatial distribution of rainfall erosivity, soil erodibility and maximum soil loss $R K L S$.

The isoerodent map for Sicily was developed by using rainfall data collected at both 172 recording and 96 non-recording rain-gauges, to use all possible rainfall information in the region (Bagarello and Ferro, 2008). Spatial variability of the $R$ factor in Sicily was assessed using the 268 point-values of this factor and a kriging technique with the GRID module of the ARC-INFO software. The analysis, developed with reference to a square cell of side length equal to $2 \mathrm{~km}$, yielded an estimate of $R$ for each cell (Figure 1). Spatial variability of $R$ was also represented by superimposing the isoerodents to the 1:250,000 map of Sicily.

Ferro (Bagarello et al., 2016) developed the map of the soil erodibility factor, $K$, according to Wischmeier et al. (1971), using data collected at more than 1800 sampling points distributed across the island (Figure 2). According to the USLE/RUSLE, the maximum soil loss, $A_{\max }$ ( $\mathrm{t} \mathrm{ha}^{-1} \mathrm{yr}^{-1}$ ), is given by the product $R K L S$, where $L$ and $S$ are the slope length and steepness factors, respectively. The $A_{\max }$ term yields the maximum soil erosion that can occur at the mean annual temporal scale when the soil is bare (cover and management factor, $C=1$ ) and antierosive measures are not applied (support practice factor, $P=1$ ). Estimation of the topographic factors was carried out using the digital elevation model of the island with a mesh size of $200 \mathrm{~m}$.

The $L$ factor was calculated by the RUSLE relationship (Renard et al., 1997) and the $S$ factor was calculated according to Nearing (1997).

The map of $A_{\max }$ for Sicily developed by Bagarello et al. (2008) is shown in Figure 3 and it can be used, according to Eq. (14), to deter- mine the areas of the island having a maximum soil loss greater than the tolerance in which soil conservation strategies are necessary.

\section{Research needs}

Nearing (2002) suggested that the tolerable soil loss established for U.S. soils could be inadequate for other regions because scientific evidence of its applicability is poor and should be updated.

Bazzoffi (2009) underlined that the concept of tolerable soil loss based on soil productivity and soil formation rate does not take into account the off-site effects of soil loss.

Taking into account that soil erosion causes a direct loss of nutrients, new research should be carried out for linking the grain-size distribution of the eroded sediment to that of the original soil in order to explain the enrichment of chemical content of the sediment with respect to the parent soil. The enrichment concept (Di Stefano and Ferro, 2002) is currently applied to clay, organic matter, and all chemicals adsorbed by soil particles, such as nitrogen and phosphorus, and it is useful to explain the off-site effects. Clay soils are dominated by aggregates, whereas non-cohesive soils are usually constituted by primary particles. Soil structure strongly influences sediment yield and the loss of chemicals that are transported in eroded sediments; aggre-

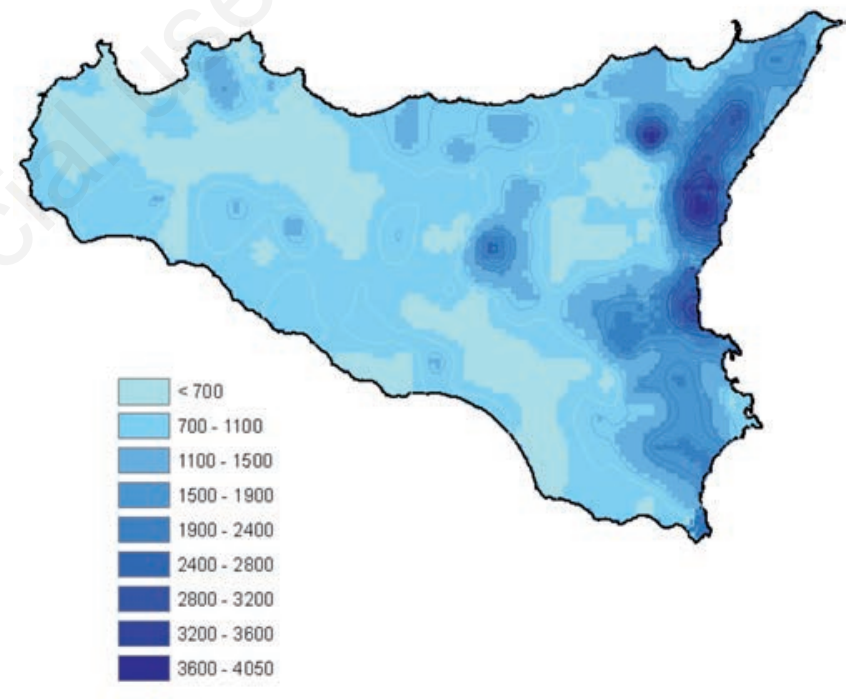

Figure 1. Rainfall erosivity map for Sicily.

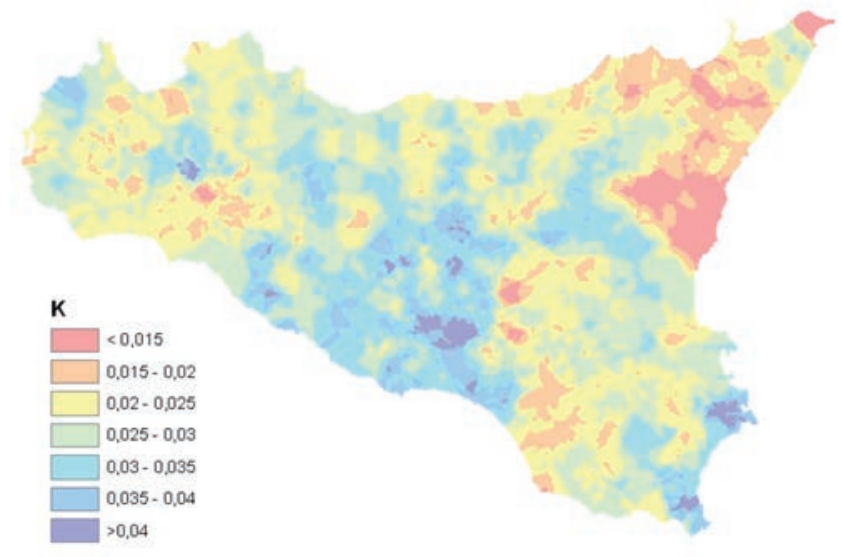

Figure 2. Soil erodibility map for Sicily. 
gational characteristics of soil particles also affect hillslope sediment transport and delivery processes. Since sediments and adsorbed chemicals are produced from different sources distributed throughout a drainage basin (Di Stefano et al., 2000), improvements in modeling chemical soil transport phenomena could be obtained by employing a spatially-distributed approach of sediment delivery processes (Ferro and Minacapilli, 1995; Ferro, 1997; Ferro et al., 1998a, 1998b; Ferro and Porto, 2000).

As suggested by Li et al. (2009) new researches should be developed to link the tolerable soil loss definition with a scientific basis supporting this definition. As an example, if $T_{S L}$ is defined as the maximum soil loss that will not reduce crop productivity over a long period a quantitative relationship between soil erosion and crop productivity, under different input conditions, has to be determined. This relationship will allow to model specific at site and anthropic conditions.

To assess how and to what extent soil loss decreases crop productivity, the multiple factors influencing soil erosion and the soil components affecting crop productivity have to be considered. Taking into account that soil erosion causes the loss of soil nutrients, depth, biota, organic matter and water resources, models able to translate these losses into reduced crop productivity are necessary.

Notwithstanding that the concept of using long-term hydrological data for a probabilistic representation of the hydrological phenomena is well known, and is currently employed for rainfall-runoff and flood studies (Ferro, 2006), the use of frequency analysis in soil erosion studies is relatively limited.

New researches are necessary to establish both the empirical frequency distribution of soil loss at different sites and the theoretical probability distribution to fit to the annual maximum soil loss measured values. An estimating criterion of the annual soil loss of a given return period can be determined and linked to a tolerable soil loss value. A new definition of the tolerable soil loss can be obtained by this frequency analysis and this threshold soil loss can be correlated to riling occurrence.

Estimating soil erosion in monetary terms is significant and underlines the importance of soil conservation strategies. The major on-site cost of erosion in agricultural fields is expended to replace the lost nutrients and water. Understanding the relationship between land-use and hydrological characteristics (runoff and soil loss) is critical to the prediction of nutrient budgets for establishing at site practices and forecasting off-site effects.

Erosion not only damages the agricultural area where it occurs but also affects the surrounding environment. The most serious of off-site damages are caused by soil particles entering the water system

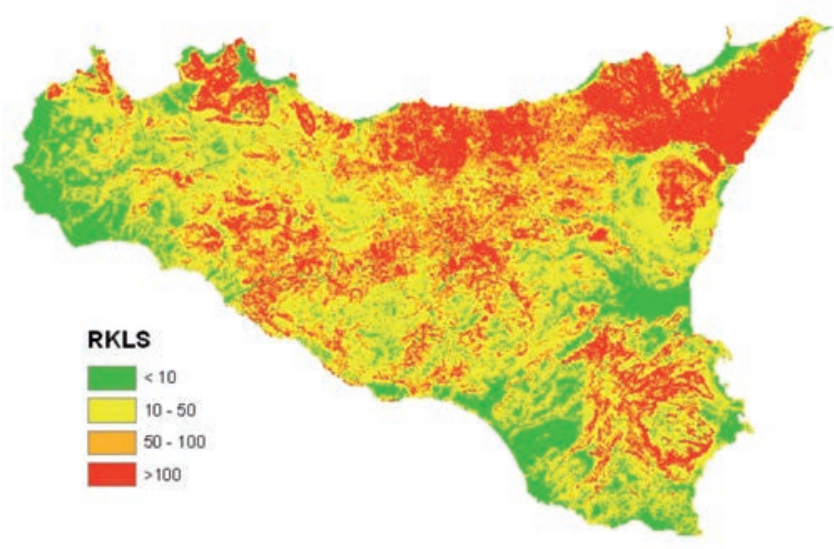

Figure 3. Map of the maximum soil loss, $A_{\max }\left(\mathrm{t} \mathrm{ha}^{-1} \mathrm{yr}^{-1}\right)$, for Sicily.
(Pimentel, 1995). Siltation is a major problem in reservoirs because it reduces water storage, shorten the lifetime and increases the maintenance costs of dams. Developing of distributed models for predicting the spatial distribution of sediment yield at basin scale is useful to establish the areas within the basin which are interested by sediment delivery processes (Jain et al., 2000; Fernandez et al., 2003; Fu et al, 2006). The areas responsible of the most basin sediment yield determine the off-site effects and should be interested by erosion control technologies and soil conservation strategies aimed to decrease soil and nutrient loss, to preserve soil's fertility and to sustain crop yields.

\section{Conclusions}

Soil loss due to erosion is a natural and inevitable phenomenon but it can become excessive, and hence intolerable, in particular situations and mostly due to anthropic factors.

Tolerable soil loss is a concept developed in the $20^{\text {th }}$ century and it is useful to judge if a soil has potential risk of erosion, productivity loss and off-site damages. The first definition of tolerance is due to Smith which, focusing on soil fertility conservation, stated that is the soil loss rate which permits at least a constant or preferably an increasing time gradient of soil fertility. Over the last 25 years more holistic definitions, taking into account both the involved soil functions and the off-site effects, were proposed. The definition of Verheijen et al. (2009) integrating soil quantity and soil functions represents a more holistic approach to tolerable soil erosion.

Being the soil loss tolerance concept useful for planning soil conservation strategies, its quantitative estimation is necessary and has to be carried out taking into account large storms rather than average conditions. For this reason research on statistical distribution of the annual maximum soil loss should be carried out in different areas of the world.

The concept of tolerable soil loss has also take into account the offsite effects of soil loss and new research should be carried out for linking the grain-size distribution of the eroded sediment to that of the original soil in order to explain the enrichment of chemical content of the sediment with respect to the parent soil.

Finally costs of soil erosion are significant and underline the importance of soil conservation strategies. Understanding the relationship between land-use and hydrological characteristics (runoff and soil loss) is critical to the prediction of nutrient budgets for establishing at site practices and forecasting off-site effects.

\section{References}

Alexander E.B. 1988. Rates of soil formation: implications for soil loss tolerance. Soil Sci. 145:37-45.

Baffaut C., Nearing M.A., Govers G. 1998. Statistical distributions of soil loss from runoff plots and WEPP model simulations. Soil Sci. Soc. Am. J. 62:756-63.

Bagarello V., Carollo F.G., Di Stefano C., Ferro V., Giordano G., Iovino M., Pampalone V. 2016. Twenty years of scientific activity at Sparacia experimental area. Quad. Idronom. Mont. 33:1-142.

Bagarello V., Di Piazza G.V., Di Stefano C., Ferro V. 2008. Il fattore di erodibilità del suolo e la carta dell'erosione potenziale. Quad. Idronom. Mont. 28:55-70.

Bagarello V., Di Stefano C., Ferro V., Pampalone V. 2015. Establishing a soil loss threshold for limiting rilling. J. Hydrol. Eng. ASCE 20:C5014001-1C5014001-12.

Bagarello V., Di Stefano C., Ferro V., Pampalone V. 2010. Statistical distribu- 
tion of soil loss and sediment yield at Sparacia experimental area, Sicily. Catena 82:45-52.

Bagarello V., Di Stefano C., Ferro V., Pampalone V. 2011. Using plot soil loss distribution for soil conservation design. Catena 86:172-7.

Bagarello V., Ferro V. 2006. Erosione e conservazione del suolo. McGraw-Hill, Milano, Italy.

Bagarello V., Ferro V. 2008. Il fattore climatico dell'equazione universale per il calcolo della perdita di suolo. Quad. Idronom. Mont. 28:37-53.

Barth T.F.W. 1961. Abudance of the elements, areal averages, and geochemical cycles. Geochim. Cosmochim. Acta 23:1-8.

Bazzoffi P. 2009. Soil erosion tolerance and water runoff control: minimum environmental standards. Reg. Environ. Change 9:169-79.

Browning G.M., Parish G.I., Glass J. 1947. A method for determining the use and limitation of rotation and conservation practices in the control of soil erosion in Iowa. J. Am. Soc. Agron. 39:65-73.

Cerdà A., Flanagan D.C., le Bissoinnais Y., Boardman J. 2009. Soil erosion and agriculture. Soil Tillage Res. 106:107-8.

Di Stefano C., Ferro V. 2002. Linking clay enrichment and sediment delivery processes. Biosyst. Eng. 81:465-79.

Di Stefano C., Ferro V., Palazzolo E., Panno M. 2005. Sediment delivery processes and chemical transport in a small forested basin. J. Hydrol. Sci. 50:697-712.

European Commission. 2006. A strategy to keep Europe's soils robust and healthy. Available from: http//ec.europa.eu/environment/soil/index_ en.htm

European Environment Agency. 1998. Europe's environment: the second assessment. Available from: http//www.eea.europa.eu//publications/92828-3351-8

Ferro V. 2006. La sistemazione dei bacini idrografici, seconda edizione. McGraw-Hill, Milano, Italy.

Ferro V., Giordano G., Iovino M. 1991. Isoerosivity and erosion risk map for Sicily. J. Hydrol. Sci. 36:549-64.

Friend J.A. 1992. Achieving soil sustainability. J. Soil Wat. Cons. Ankeny 47:156-7.

Gonzales-Hidalgo J.C., Batalla R.J., Cerdà A., De Luis M. 2010. Contribution of the largest events to suspended sediment transport across the USA. Land Degrad. Dev. 21:83-91.

Gonzales-Hidalgo J.C., Batalla R.J., Cerdà A., De Luis M. 2012. A regional analysis of the effects of largest events on soil erosion. Catena 95:85-90.

Hession W.C., Storm D.E., Haan C.T. 1966. Two-phase uncertainty analysis: an example using the universal soil loss equation. Trans. ASAE 39:1309-19.

Huber S., Prokop G., Arrouays D, eds. 2008. Environmental assessment of soil for monitoring. Volume I indicators and criteria. Office for the Official Publications of the European Communities, Luxembourg, Luxembourg.

Johnson L.C. 1987. Soil loss tolerance: fact or myth? J. Soil Water Conserv. 42:155-60.

Johnson L.C. 2005. Soil loss tolerance: fact or myth. J. Soil Water Conserv. 60:155-60.

Kendall H.W., Pimentel D. 1994. Constraints on the expansion of the global food supply. Ambio 23:198-205.

Lakaria B.L., Biswan H., Mandal D. 2008. Soil loss tolerance values for different physiographic regions of central India. J. Soil Use Manag. 24:192-8.

Lal R. 1998. Soil erosion impact on agronomic productivity and environment quality. Crit. Rev. Plant Sci. 17:319-464.

Lal R. 2001. Soil degradation by erosion. Land Degrad. Develop. 12:519-39.

Larson W.E. 1981. Protecting the soil resource base. J. Soil Water Conserv. 36:13-6.

Larson W.E., Lindstrom M.J., Schumacher T.E. 1997. The role of severe storms in soil erosion: a problem needing consideration. J. Soil Water Conserv. 52:90-5.

Lenka N.K., Mandal D., Sudhishri S. 2014. Permissible soil loss limits for dif- ferent physiographic regions of West Bengal. Curr. Sci. 107:665-70.

Li L., Du S., Wu L., Liu G. 2009. An overview of soil loss tolerance. Catena 78:93-9.

Mannaerts C.M., Gabriels D. 2000. A probabilistic approach for predicting rainfall soil erosion losses in semiarid areas. Catena 40:403-20.

Montgomery D.R. 2007. Soil erosion and agricultural sustainability. PNAS 104:13268-72.

Miklos A.A. 1992. Biodynamique d'une coverture pédologique dans la region de Botucatu (SP). Degree Diss., University of Paris IV, Paris, France.

Nearing M.A. 1997. A single continuous function for slope steepness influence on soil loss. Soil Sci. Soc. Am. J. 61:917-9.

Nearing M. 2002. Toward a new definition of soil loss tolerance for the United States. Proc. Int. Soil Conservation Organization Conference, May 26-31, Beijing, China.

Owens L.B., Watson J.P. 1979. Rates of weathering and soil formation on granite in Rhodesia. Soil Sci. Soc. Am. J. 43:160-6.

Panagos P., Borrelli P., Ballabio C., Lugato E., Meusburger K., Montanarella L., Alewell C. 2015. The new assessment of soil loss by water erosion in Europe. Environ. Sci. Policy 54:438-47.

Pimentel D., Harvey C., Resosudarmo P., Sinclair K., Kurz D., McNair M., Crist S., Shpritz L., Fitton L., Saffouri R., Blair R. 1995. Environmental and economic costs of soil erosion and conservation benefits. Science 267:1117-23.

Renard K.G., Foster G.R., Weesies G.A., McCool D.K., Yoder D.C. 1997. Predicting soil erosion by water. A guide to conservation planning with the revised universal soil loss equation RUSLE. USDA Agriculture Handbook No 703. U.S. Department of Agriculture, Washington, DC, USA.

Schmidt B.L., ed. 1982. Determinants of soil loss tolerance. ASA Publication No. 45. American Society of Agronomy, Madison, WI, USA.

Smith D.D. 1941. Interpretation of soil conservation data for field use. Agr. Eng. 22:173-5.

Smith D.D., Whitt D.M. 1948. Evaluating soil losses from field area. Agr. Eng. 29:394-8.

Sparovek G., De Jong V.Q. 1997. Definition of tolerable soil erosion values. Rev. Bras. Cienc. Solo 21:467-71.

Strohmeier S., Laaha G., Holzmann H., Klik A. 2016. Magnitude and occurrence probability of soil loss: a risk analytical approach for the plot scale for two sites in lower Austria. Land Degrad. Develop. 27:43-51.

Toy T.J., Foster G.R., Renard K.G. 2002. Soil erosion: processes, prediction, measurement, and control. Wiley, New York, NY, USA.

USDA (U.S. Department of Agriculture). 1956. Agricultural Research Service and Soil Conservation Service. Joint Conference on Slope-Practice, Washington, DC, USA

Uri N.D. 2000. Agriculture and environment - The problem of soil erosion. J. Sustain. Agric. 16:71-94.

Verheijen F., Jones R., Rickson R., Smith C. 2009. Tolerable versus actual soil erosion rates in Europe. Earth Sci. Rev. 94:23-38.

Wakastsuki T., Rasyidin A. 1992. Rates of weathering and soil formation. Geoderma 52:251-63.

Williams J.R. 1981. Soil erosion effects on soil productivity. A research perspective. J. Soil Water Conserv. 36:82-90.

Wischmeier W.H., Smith D.D. 1978. Predicting rainfall erosion losses: a guide to conservation planning. USDA Agriculture Handbook № 537. U.S. Department of Agriculture, Washington, DC, USA.

Wischmeier W.H., Johnson C.B., Cross B.V. 1971. A soil erodibility nomograph for farmland and construction sites. J. Soil Water Conserv. 26:189-93.

Zhao G., Mu X., Wen Z., Wang F., Gao P. 2013. Soil erosion, conservation, and ecoenvironments changes in the loess plateau of China. Land Degrad. Develop. 24:499-510. 